\title{
ATTRAVERSIAMO IL FIUME
}

Waleska Rodrigues M. O. MARTINS ${ }^{1}$

- Senta um pouco.

O rio na garganta, o toque da realidade no lábio, tudo é um instante de lucidez. As mãos curvas, linhas longas, profundas marcas azuis que saltam da pele, dançam no nada. Vômito.

- Calma, tudo vai ficar bem.

Os olhos tentam fixar a voz. Alcançaria, se a alma estivesse presa em si, o riso infante que atravessa ao longe, ao fundo, na cólera do tempo. Calafrio.

- Me dê sua mão.

Os olhos, profundas cavidades inertes, saltam no mármore. Cada osso empurra violentamente a pele resseca. $\mathrm{O}$ abutre lhe estraçalha a voz. Quer prender a pomba predileta. Voou.

Convulsões, cólicas brutas no ventre.

- Vem comigo.

Nada de vômito, nada de calafrios.

O silêncio se abre no fechar dos olhos.

\footnotetext{
${ }^{1}$ Doutoranda em Estudos Literários - Unesp/Araraquara
} 